Medline search. This showed that during 1982-6 nine papers included the phrase in their titles with a further 59 using it in the abstract. During 1987 91 these figures jumped to 35 and 373 respectively. These figures do not include other papers that use the phrase elsewhere in the text.

A close inspection of these 35 recent publications indicates that the use is subject to considerable criticism. In 19 cases the designation gold standard is questioned in such varied conditions as depression ${ }^{3}$ left ventricular function, ${ }^{4}$ osteoporosis, ${ }^{5}$ and gastro-oesophageal reflux. ${ }^{\circ}$ This is not surprising, I suppose, as these are clinical conditions that are not amenable to the certainty implied in the term.

Because the phrase smacks of dogma its use should be discontinued in medical science. After all, the financiers gave up the idea of a gold standard decades ago.

P FINBARR DUGGAN

\section{Biochemistry Laboratory,}

Cork Regional Hospital

Wilton,

Cork,

Republic of Ireland

I Johnson RN, Metcalf PA, Baker JR. Fructosamine: a new approach to the estimation of serum glycosylprotein. An index approach to the estimation of serum glycosylprotein.

2 Jeffreys AJ, Wilson V, Thein SL. Individual-specific "finger prints" of human DNA. Nature 1985;316:76-9.

3 Gerber PD, Barrett J, Barrett J, Manheimer E, Whiting R, Smith $R$. Recognition of depression by internists in primary care: a comparison of internist and "gold standard" psychiatric assessments. F Gen Intern Med 1989;4:7-13

4 Vine DL. Left ventricular function: is it a gold standard for comparing thrombolytic agents? Kans Med 1990;91:215-6.

Michel D. Mineral content and bone density: a gold standard for osteoporosis? Fortschr D Med 1989;107:16-7.

6 Mela GS, Savarino V. Doubt on pH-metry as an absolute gold standard for measuring acid gastroesophageal reflux. Digest $D i s$ Sci 1990;35:282-3.

\section{Provision of home births}

EDITOR,-As midwives and general practitioners who regularly attend women giving birth at home we wish to respond to recent correspondence on maternity services.'

For many families the only non-clinical bar to women choosing home birth is the refusal of their general practitioner to attend or sanction it. Community midwives are bound in law to attend if requested, although general practitioners need do so only in an emergency. As most community midwives we know regard home birth as not only the aspect of their work that gives them most satisfaction but the prime reason for choosing to work in the community, we are concerned that it is the medical profession that seems to be the impediment.

We support home birth: firstly, because of a woman's right of choice and our responsibility to ensure that the choice is fully informed; secondly, because our experience of attending home births shows that for some women home is the best place of delivery; and, thirdly, because there is sufficient evidence to show that low risk women fare as well at home as in hospital. ${ }^{2}$ We are concerned at the false premises that are used as arguments to refuse home births - for example, that low risk is a retrospective diagnosis (a contradiction in terms); that the national improvement in perinatal mortality is significantly related to the change in policy from home to hospital delivery; and that transfers into hospital (which do not take into account unattended unplanned births) are associated with a high perinatal mortality. Similarly, bad experiences during the $1960 \mathrm{~s}^{\prime}$ are no longer relevant.

Time has moved on and national circumstances have changed-for example, ambulance paramedical teams have been upgraded to replace flying squads. The Commons select committee has therefore rightly suggested that we should look again at home birth in view of the strongly expressed desire of midwives and a cohort of women to keep this option alive. Doctors should not allow themselves to be seen as unable to accept unwelcome data as facts. Home birth will continue as a minority option but on present evidence could increase from $1 \cdot 2 \%$ to between $5 \%$ and $10 \%$ of al births. We believe that it is in all our interests that we should allow home birth to find its own level. KATRINA ALLEN EPPY SEWELL CAROL CHEAL JIM SIKORSKI BRIDGET CLARK SIAN THOMAS NICKY LEAP

London SE24 9HE

1 Correspondence. Maternity services. BMF 1992;304:1056-7. (18 April.)

2 Campbell R, Beral V, MacDonald Davies I, MacFarlane A. Home births in England and Wales, 1979: perinatal mortality according to intended place of delivery. BMF 1984;289:721-4.

\section{Psychological treatments for patients with cancer}

EDITOR,-Commenting on the study by Steven Greer and colleagues,' Patricia McHugh and Shôn Lewis advocate wider adoption of psychologica therapy for patients suffering from cancer. ${ }^{2}$ This is a laudable aim, but large numbers of patients need psychological treatments and these treatments tend to be lengthy: Greer and colleagues reported a method that took six one hour sessions. Where is the time for such skilled work to come from? $\mathrm{McHugh}$ and Lewis consider that a serious look should be taken at some new initiatives without stating what these are.

The only practical way to deliver psychological treatment to large numbers of people is to incorporate self help techniques so that the patients in effect conduct their treatment with only a small input of time from the therapist. One such technique, which focuses on anxiety, which lies at the root of much distress in serious somatic disease, is anxiety control training. ${ }^{3}$ This is a method that I based on medicational practice; it is easily taught, is acceptable to patients, and takes about six 10 minute sessions. Colleagues and I recently concluded a follow up study in phobic patients and showed that improvement continues after sessions with the therapist have stopped so long as the patient continues to conduct the 10 minute practice sessions at home. ${ }^{+}$The technique can easily be conducted on a domiciliary basis by community nurses and is, I suggest, just the type of procedure that should be researched in cancer.

Academic Unit of Psychiatry,

PHILIP SNAITH

St James's University Hospital,

Leeds LS9 7TF

1 Greer S, Moorey S, Baruch JDR, Watson M, Robertson BM, Mason A, et al. Adjuvant psychological therapy for patients wason A, $c$ al. Adjurt psychlogical therapy for patien with cancer: a prospec
675-80. (14 March.)

$2 \mathrm{McHugh} P$, Lewis S. Psychological treatments in cancer patients. BMf 1992;304:1247-8. (9 May.)

3 Snaith P. Clinical neurosis. 2nd ed. Oxford: Oxford University Press, 1991.

4 Snaith RP, Owens DW, Kennedy E. An outcome study of a bric anxiety management programme: anxiety control training. Irish f Psychol Med (in press)

\section{Cholera in Brazil}

EDITOR, - Having just returned from our medical student elective in Brazil, we know that cholera has spread far into Brazil since P D Marsden wrote the letter from Brasília': during March and April cases began to occur in the major cities of the north east coast, infected carriers travelling south by road or air from the Amazon basin. In the small coasta state of Pernambuco alone over 1200 cases had been reported by early May. In the first week of
May cholera was confirmed in Bahia, only two states north of Rio de Janeiro, and at the airport of Foz do Iguaçu, Paraná state, on Brazil's southern border with Argentina.

Standards of sanitation are poor in the shanty towns of every big city and in the countryside: $70 \%$ of Brazil's 145 million people do not have proper drainage, and $15 \%$ have no access to clean drinking water. Newspaper coverage of the dangers, however, is extensive, and there are many educational posters. Information leaflets illustrating hygiene and sanitary measures are distributed at bus stations and airports; Ministry of Health officials meet intercity buses and check that no passengers have symptoms; and an announcement warning of the symptoms of cholera is made during domestic air flights. The Ministry of Health runs a campaign on television and through schools to educate people about oral rehydration therapy; sachets of oral rehydration salts are available free from every health post, and double ended plastic spoons for making up home made sugar and salt preparations are distributed through churches by the Brazilian conference of bishops. Amazonian Indians in some areas have had large tanks for collecting rainwater installed in their villages so that they no longer need to drink untreated river water.

Despite the efforts of the Ministry of Health it seems likely that cholera will soon spread to the major conurbations of Rio de Janeiro and Sao Paulo with devastating effects on the poor populations there.

JANE L ASHWORTH SIMON A SHIELDS

John Radcliffe Hospita

Oxford OX3 9DU

1 Marsden PD. Cholera. BMJ 1992;304:1170-1. (2 May.)

\section{Treatment of elderly patients with breast cancer}

EDITOR,-J Michael Dixon's editorial on the treatment of elderly patients with breast cancer ${ }^{1}$ prompted us to carry out a subgroup analysis of the 198 patients aged $70-80$ in the Scottish adjuvant tamoxifen trial who were randomised to tamoxifen either for five years after mastectomy or for treatment of their first relapse. ${ }^{2}$

Although the numbers in the subgroups were unequal ( 89 patients were given tamoxifen as adjuvant treatment and 109 after relapse), the treatment groups were comparable (table). Alto-

Median age and distribution of other variables (number (percentage)) for 198 patients aged $\geqslant 70$ at entry in the treatment arms of Scottish adjuvant tamoxifen trial

\begin{tabular}{lcc}
\hline & $\begin{array}{c}\text { Adjuvant } \\
\text { tamoxifen } \\
(\mathrm{n}=89)\end{array}$ & $\begin{array}{c}\text { Tamoxifen } \\
\text { after relapse } \\
(\mathrm{n}=109)\end{array}$ \\
\hline $\begin{array}{l}\text { Median age at entry (years) } \\
\text { Nodal status: }\end{array}$ & $73 \cdot 0$ & $73 \cdot 7$ \\
$\quad$ Negative & & \\
$\quad$ Positive & $46(52)$ & $58(53)$ \\
$\begin{array}{l}\text { Tumour size: } \\
\quad<2 \mathrm{~cm}\end{array}$ & $33(37)$ & $40(37)$ \\
$\quad>5 \mathrm{~cm}$ & $20(22)$ & $24(22)$ \\
$\begin{array}{l}\text { Oestrogen receptor status: } \\
\quad \text { Poor }(<20 \text { fmol) }\end{array}$ & $5(6)$ & $7(6)$ \\
$\quad$ Rich $(\geqslant 20$ fmol) & $14(16)$ & $17(16)$ \\
Postoperative radiotherapy & $32(36)$ & $39(36)$ \\
& $23(26)$ & $33(30)$ \\
\hline
\end{tabular}

gether $19(21 \%)$ and $28(26 \%)$ respectively had postoperative radiotherapy because of a positive node sample, the remainder of those given radiotherapy being randomised to it because the surgeon had failed to remove a node for examination. Only half of each group had oestrogen receptor assays carried out. Thirty seven of the patients given adjuvant tamoxifen $(42 \%)$ and 65 of those given tamoxifen after relapse $(60 \%)$ are now dead.

Our findings in this age group suggest that 